\title{
Platon i Arystoteles. Relacja mistrz - uczeń we wczesnej Akademii
}

\author{
Plato and Aristotle: the Master- \\ Student Relationship in the Early Academy
}

\begin{abstract}
ABSTRAKT
Celem artykułu jest analiza relacji mistrz - uczeń na przykładzie stosunku, jaki łączył Platona, założyciela Akademii, z Arystotelesem, jej najwybitniejszym wychowankiem. Stagirytę postrzega się zazwyczaj jako odstępcę od platonizmu. Jest to uzasadnione tylko wtedy, kiedy relację mistrz - uczeń postrzega się w paradygmacie szkolnym. $\mathrm{Na}$ podstawie analizy zachowanych świadectw oraz dyskusji, jaka toczy się wśród współczesnych badaczy na temat wczesnej Akademii, wysuwam w artykule twierdzenie, że Platon stworzył nowy model współpracy z uczniami, który określiłem jako „naukowy”. Charakteryzuja go: brak ortodoksyjnej doktryny we wczesnej Akademii, otwarte dyskusje mistrza z uczniami nad założeniami i aporiami nauki o Ideach, absolutna swoboda akademików w prowadzeniu samodzielnych badań, ich intelektualna niezależność, prowadzqca nawet do odrzucenia nauk mistrza. W wypadku Arystotelesa poskutkowało to nie tylko sformułowaniem oryginalnych koncepcji w ramach fizyki, metafizyki, polityki i etyki, ale także innym modelem pracy naukowej i praktyki pedagogicznej, jakie zastosował w swojej własnej szkole. Mimo to wysuwam wniosek, że Stagirytę należy określać jako prawdziwego platonika - wiernego ucznia i najwybitniejszego kontynuatora nauk
\end{abstract}

StOWA KLUCZOWE Akademia, Platon, Arystoteles, mistrz, edukacja filozoficzna

\section{KEYWORDS}

Academy, Plato, Aristotle, master, philosophical education

SPI Vol. 24, 2021/3

ISSN 2450-5358

e-ISSN 2450-5366 DOI: 10.12775/SPI.2021.3.001

Nadestano: 4.07.2021 Zaakceptowano: 17.09.2021

Artykuły i rozprawy 
mistrza. Arystoteles pozostał bowiem wierny najistotniejszemu przesłaniu Platona: że filozoficzny model życia - bios theoretikos - stanowi powołanie człowieka.

\section{ABSTRACT}

The aim of the article is to analyze the master - student relationship by means of the example of the relationship between Plato, the founder of the Academy, and Aristotle, his most outstanding pupil. Aristotle is usually seen as a critic and traitor of Platonism. This thesis is only justified if the master - student relationship is perceived in the school paradigm.

Based on the analysis of preserved testimonies and a discussion about the early Academy among contemporary scholars, I claim that Plato created a new model of collaboration with his students, which I described as "scientific". It is characterized by: the lack of orthodox doctrine in the early Academy, open discussions between the master and his students over the assumptions and difficulties of his doctrine of Ideas, absolute freedom of Academy members to conduct independent research, their intellectual independence, even leading to the rejection of the doctrine of the master. In Aristotle's case, this not only resulted in the formulation of original concepts within physics, metaphysics, politics and ethics, but also in another model of scientific work and pedagogical practice in his own school. Nevertheless, I firmly define Aristotle as a true Platonist and the most outstanding continuator of his master's teaching. Aristotle remained faithful to Plato's most important message: that the philosophical model of life - bios theoretikos - is a vocation of man.

\section{Wprowadzenie}

Istnieją, moim zdaniem, dwa podstawowe modele, w jakich realizuje się wychowawcza i edukacyjna relacja mistrz - uczeń: szkolny i naukowy. Model szkolny oparty jest bądź na pierwszeństwie doktrynalnym mistrza - w tym wypadku uczniowie głoszą i rozwijają nauki swego mistrza, broniąc ich przed atakami przeciwników - bądź na doskonałej specjalizacji nauczyciela, jego „wtórnym” mistrzostwie w rozumieniu wykładanej doktryny, interpretowaniu jej niuansów i tłumaczeniu słuchaczom. W starożytnych szkołach filozoficznych łatwo odnajdziemy przykłady wymienionych odmian: Epikur był dla 
swoich uczniów z całą pewnością mistrzem w pierwszym znaczeniu, natomiast późniejsi kontynuatorzy Platona i Arystotelesa, jak Proklos czy Aleksander z Afrodyzji - w drugim. Scholastyka uprawiana na średniowiecznych uniwersytetach utrwaliła wzorzec nauczyciela jako reprezentującego ten drugi typ szkolnego „mistrzostwa”. Ówcześni wykładowcy opierali bowiem nauczanie na autorytecie (Pisma św. i dzieł Arystotelesa) i ograniczali się do roli komentatorów. Zupełnie inny model relacji mistrz - uczeń (określiłem go wyżej jako „naukowy”) wykształcił się w pozaszkolnej tradycji wychowawczej w antyku. Miał on swe źródła w tym, co w okresie klasycznym nazywano archaia paideia (termin znany nam przede wszystkim z Chmur Arystofanesa), ale miejscem jego pełnego ukształtowania była Akademia Platona. Nie jest z mojej strony niekonsekwencją, że nazwałem ten model "pozaszkolnym” - Akademia w tym czasie nie była bowiem „szkołą".

Chciałbym w niniejszym artykule zanalizować ten naukowy model relacji mistrz - uczeń na przykładzie stosunku, jaki łączył Platona, założyciela Akademii, z Arystotelesem, jej najwybitniejszym wychowankiem. Stagirytę postrzega się tradycyjnie (także dzisiaj) jako odstępcę od platonizmu (stosuję tu terminologiczne rozróżnienie między „Platonizmem”, jako nauką samego Platona, a "platonizmem", głoszonym w różnych odmianach przez jego uczniów i następców). Jest to uzasadnione tylko wtedy, kiedy relację mistrz uczeń postrzega się w paradygmacie szkolnym. W odniesieniu do Akademii Platona jest to błąd.

\section{Świadectwa dotyczące relacji między Platonem a Arystotelesem}

Nie jest łatwo pisać o relacji, jaka łączyć mogła Platona i Arystotelesa - mamy bardzo mało „twardych” danych w tej kwestii. Doniesienia o ich osobistych relacjach są późniejsze i mają charakter anegdot, które nie układają się w spójny obraz. Według jednej tradycji, Platon wyrażał się o swoim młodym uczniu z uznaniem, o czym mógłby świadczyć akademicki przydomek Arystotelesa - nous (rozum, umysł). Z kolei określenie „czytelnik”, którym według autora Vita Marciana (6, s. 98) scharakteryzował Platon główne zamiłowanie Arystotelesa, sugerowałoby jakąś różnicę w postawie naukowej obu myślicieli. Niektórzy starożytni doksografowie postrzegali Arystotelesa jako 
najwybitniejszego ucznia Platona, a założenie Likejonu - jako chęć kontynuowania Platońskich nauk (Diogenes Laertios 1988: V,1-3), ale nie brak też doniesień, jakoby Arystoteles miał pod koniec życia swego mistrza odnosić się doń arogancko, a nawet czyhać na stanowisko kierownika szkoły (Berti 2016: 17). Taka sprzeczność w doniesieniach jest typowa dla okresu hellenistycznego, kiedy szkoły filozoficzne najsilniej ze sobą rywalizowały i każda próbowała tworzyć własną tradycję dotyczącą początków filozofii i modeli filozoficznego życia, i kiedy dzieje samej filozofii zaczęto przedstawiać w kanonie historii szkół i sukcesji (Jaeger 1948: 426-461). Doprawdy, trudno o mniej wiarygodne świadectwa w interesującej nas kwestii.

W tekstach Platona nie odnajdziemy żadnych wskazówek na temat jego relacji z Arystotelesem. W dialogu Parmenides pojawia się co prawda postać o takim imieniu, ale czy była to ze strony autora jakaś aluzja - nie wiemy. W zachowanych pismach Arystotelesa z kolei mamy jeden, za to słynny fragment, który jasno charakteryzuje stosunek Stagiryty do swego mistrza: „Zdaje się chyba jednak, że może lepiej jest i że trzeba dla ocalenia prawdy poświęcić nawet to, co jest nam bardzo bliskie - zwłaszcza jeśli się jest filozofem; bo gdy jedno i drugie jest drogie, obowiązek nakazuje wyżej cenić prawdę [niżeli przyjaciól]" (Etyka nikomachejska 1096a 14-17). Opinia ta, przetransponowana wieki później na łacińskie przysłowie $A m i-$ cus Plato, sed magis amica veritas, ufundowała tradycyjny wizerunek Arystotelesa jako krytyka Platońskiej nauki o Ideach. To, że Stagiryta krytykował Idee (ta eide), jest niewątpliwe. Ale, po pierwsze, nie zawsze wiemy, czy w danym miejscu krytykuje on akurat doktrynę Platona, czy innych platoników z Akademii (zauważmy, że nawet w przywołanym wyżej fragmencie imię Platona się nie pojawia), a po drugie, sens tych uwag jest mniej krytyczny niż się na ogół sądzi. Przytoczony fragment Etyki nikomachejskiej odczytywany też jest jako wyraz szacunku i przyjaźni, jakie żywił Stagiryta dla Platona jako swego nauczyciela - mimo różnic w poglądach. Potwierdza to napisana po śmierci Platona Elegia do Eudemosa, w której Arystoteles mówi o swoim mistrzu: „człowiek, którego złym ludziom chwalić się nie godzi” (Berti 2016: 18). 


\section{Co wiemy o wczesnej Akademii}

Drugie poważne ograniczenie dla naszych rozważań stanowi niemal całkowity brak informacji na temat działalności naukowo-wychowawczej Akademii w czasach Platona. Nie wiemy jaka była wewnętrzna struktura tej instytucji, jak przebiegała rekrutacja, jaką rolę przypisał sobie Platon jako jej „scholarcha”, w szczególności zaś - w jaki sposób nauczał, czy istniał jakiś program nauczania, a nawet - w jakim celu została założona. We wszystkich tych kwestiach zdani jesteśmy jedynie na przypuszczenia (Paczkowski 2009: 355-363). Spróbujmy, mimo to, zmierzyć się z zagadką wczesnej Akademii, bazując na skąpej wiedzy, którą dysponujemy.

Platon założył Akademię około 387 r. p.n.e., po powrocie z pierwszej wyprawy do Syrakuz. Można przypuszczać, że osobiste doświadczenie głębokiej przyjaźni, jaka połączyła go wtedy z młodszym o dwadzieścia lat Dionem i która przetrwała do śmierci tego ostatniego, było jedną z najważniejszych przyczyn utworzenia wspólnoty, umożliwiającej jej członkom prowadzenie filozoficznego sposobu życia. W dialogu Fajdros (277a), który wyznacza granicę między okresem średnim a późnym w pisarskiej twórczości Platona, mówi on wprost, że największe szczęście, jakie dostępne jest tu, na ziemi, daje zapładnianie umysłów. Filozofia jako życie na podobieństwo bogów (Uczta 212a; Teajtet 176b) jest oglądaniem rzeczy najpiękniejszych (theoria), ale jako życie wśród ludzi - jest ona wychowaniem (psychagogia). Gdyby Platon chciał założyć szkołę - taką, jaką kilka lat wcześniej założył w Atenach Izokrates - przeznaczyłby na ten cel specjalny budynek, opracował program kształcenia i ustalił czesne. Zrobił odwrotnie: zajęcia odbywały się w miejscu publicznym i były dostępne dla każdego, kto chciał się przyłączyć do dyskusji. Nie było żadnego programu kształcenia ani systemu graduacji. Od członków Akademii nie pobierano żadnych statutowych opłat (wprowadził je dopiero Speuzippos; Diogenes Laertios 1988: IV, 2), a niektórzy z nich spędzili tam całe życie. Akademia nie musiała mieć żadnego statusu prawnego (Vinogradoff 1922: 119-127), była nieformalną wspólnotą, której członków łączyła przyjaźń, zainteresowania naukowe, chęć prowadzenia podobnego sposobu życia. W istocie, była to duchowa polis, która zastąpiła jej członkom przynależność do ich rodzimych państw. Przy wszystkich różnicach, w tym aspekcie 
Akademię przyrównać można do tego, czym dla chrześcijan będzie Kościół.

Platon założył Akademię w gimnazjonie o tej nazwie, a więc w miejscu publicznym, związanym z codziennym życiem Ateńczyków i służącym również religijnym obrzędom (Lynch 1972: 61). Jego prywatną własnością (a potem prywatną własnością jego kolejnych następców na stanowisku scholarchy) stał się jedynie ogród pod murami Akademii i mały budynek znajdujący się na tym terenie. Gimnazjony były w tym czasie miejscami nieformalnego wychowania obywatelskiego - młodzi spędzali w nich wolny czas (schole) pod opieką gimnazjarchy oraz dorosłych obywateli. Na takim właśnie „wspólnym obcowaniu” (synousia) polegała archaia paideia, jednak $\mathrm{w}$ drugiej połowie $\mathrm{V}$ w. p.n.e. gimnazjony stały się także miejscem wystąpień sofistów (Diogenes Laertios 1988: IX, 54), co konserwatywnie nastawiona część społeczeństwa ateńskiego oceniała jako szkodliwe dla tradycyjnego wychowania. Nie bez wpływu na oskarżenie Sokratesa o deprawowanie młodzieży był fakt, że on także prowadził swoje dysputy w gimnazjonach, dialogi Platona miały jednak na celu oczyszczenie Sokratesa z tego zarzutu i przedstawienie go jako prawdziwego wychowawcę i nauczyciela arete politike. I taki Sokrates - jak możemy oceniać - był alter ego Platona, który sam pragnął w Akademii realizować ideał wychowawczy, do którego archaia paideia nigdy nawet nie zdołała się zbliżyć. Ideał ten oparty był na wychowaniu przez synousia, nie zaś przez wykład doktrynalnych treści - co go odróżniało od praktyki sofistów. Jednocześnie bazował na kształceniu pewnych umiejętności - co go z działalnością nauczycielską sofistów pozornie łączyło, ale ową techne nie była retoryka i erystyka, sztuka przemawiania i wygrywania sporów, lecz dialektyka - metoda dochodzenia do prawdy poprzez umiejętnie prowadzoną dyskusję.

Dość powszechnie przyjmuje się dziś hipotezę, że zakładając Akademię kierował się Platon celami wychowawczo-politycznymi, nie zaś naukowymi. Wbrew opinii niektórych uczonych (Reale 1999: 105), nie znaleźlibyśmy chyba w antyku jakiegoś pierwowzoru współczesnych uniwersytetów - instytucji kształcących specjalistów w poszczególnych dziedzinach nauk humanistycznych i matematyczno-przyrodniczych. Mają one swoje korzenie raczej w szkolnictwie średniowiecznym. W antyku natomiast powstały placówki służące 
prowadzeniu specjalistycznych badań naukowych, czyli pierwowzory współczesnych instytutów badawczych. Pierwszą był Arystotelesowski Perypat, a najbardziej znacząca - aleksandryjskie Muzejon, stworzone zresztą na wzór Likejonu przez perypatetyków, Stratona i Demetriosa. Zbierano w nich materiały i informacje naukowe z różnych dziedzin, tworzono historię problemów i teorii, próbując wskazać lub zaproponować najlepszą. Wzór dla tego typu działalności stanowić mogły badania Arystotelesa w Fizyce, jednym ze źródeł gatunku literackiego prozy naukowej, nazywanego synagoge (Bloch 1940: 303-376).

Akademii Platona nie można jednak uważać ani za pierwowzór uniwersytetów, ani instytutów badawczych i towarzystw naukowych (Cherniss 1945: 61 n.). Nie ma też żadnych świadectw potwierdzających - zakładane przez wielu badaczy (Reale 1999: 103) - jej podobieństwo do związków pitagorejskich; wręcz przeciwnie - przypisywany Olimpiodorowi Żywot Platona (61, s. 387) wyraźnie zaprzecza istnieniu „tajemnych” nauk w Akademii, sekretnych procedur przyjmowania członków, konieczności przestrzegania jakichś zakazów (tabu), a także nakazu traktowania słów mistrza jako niepodważalnych (słynne autos epha, „on sam powiedział”).

Akademia była miejscem otwartym dla wszystkich, przynajmniej część zajęć odbywała się publicznie i mogli się do nich włączać przypadkowi słuchacze (Atenajos II, $59 \mathrm{~d}-\mathrm{f}$ ). Członkowie Akademii tworzyli społeczność, która nie miała żadnej formalnej struktury. Jedyny podział, jaki mógł wśród nich obowiązywać, to ten znany nam z Likejonu - na starszych (prosbyteroi) i młodszych (neaniskoi) (Diogenes Laertios 1988: V, 53 i 70-71). Taką w każdym razie hierarchię sugeruje satyra Epikratesa (fr. 11). Nie było formalnego podziału na nauczycieli i uczniów ani różnych stopni kształcenia, a rola Platona jako scholarchy zawsze opisywana jest jako „pierwszego wśród równych" (Lynch 1972: 55).

Chociaż nie wiemy, jak odbywał się nabór do Akademii, to ze świadectw wynika, że nikomu nie broniono wstępu do niej (Saffrey 1968: 67-87), nawet jeśli nie wszystkich przyjmowano ciepło, jak to podobno miało miejsce w przypadku Eudoksosa (Diogenes Laertios 1988: VIII, 87). Akademia szybko zyskała sławę w całej Helladzie, Platon nie musiał jej reklamować, ale niektóre z dialogów pisał 
z pewnością w celach protreptycznych (Nock 1933: $165 \mathrm{nn}$.), a rozmaite świadectwa potwierdzają ich skuteczność w tym względzie.

To na podstawie Listu VII (325a nn.) przypuszczamy, że celem Akademii Platona było wychowanie przyszłych prawodawców; taka też była opinia starożytnych. W istocie, lista Akademików, którzy zaangażowali się $\mathrm{w}$ działalność polityczną, jest imponująca. Byli wśród nich reformatorzy praw, zabójcy tyranów, twórcy konstytucji (jak sam Arystoteles, który nadał prawa rodzinnej Stagirze; Lynch 1972: 59).

\section{Platon jako nauczyciel i mistrz w Akademii}

Jak mogło wyglądać nauczanie w Akademii? Pytanie to wywołuje szereg bardziej szczegółowych, na przykład o to, jak należy rozumieć określenie agrapha dogmata, użyte przez Arystotelesa w Fizyce (209b) w kontekście analizy pewnego fragmentu dialogu Timajos. Jednakże tzw. nowa interpretacja i wywołany przez nią spór o nauki niepisane nie budzi dziś takich emocji, jak jeszcze w ostatnich latach XX wieku (Reale 1996: Wprowadzenie), a słynny wykład o Dobru (Arystoksenos, Elementa Harmonica II, 1) uważany jest powszechnie za spektakularną, co prawda, ale jednorazową porażkę Platona w próbie publicznego wyłożenia swoich zaawansowanych koncepcji, dlatego pominiemy te kwestie, a zajmiemy się świadectwami dotyczącymi regularnej i typowej działalności Platona jako nauczyciela i mistrza. Są one, niestety, bardzo skąpe, pozwalają jednak na twierdzenie, że Akademia nie była miejscem systematycznego wykładania jakiejś doktryny filozoficznej ani przekazywania wiedzy z zakresu dyscyplin naukowych, takich jak matematyka, astronomia czy biologia.

Satyryczne testimonium Epikratesa parodiuje metodę podziału i klasyfikacji, którą znać mógł każdy czytelnik Platońskiego Sofisty czy dzieł Speuzipposa. Cherniss podważa wartość tego świadectwa, przyrównując je do Arystofanesowych Chmur (Cherniss 1945: 63), o wiele większą rangę przypisując przytoczonemu z drugiej ręki testimonium Eudemosa. Według tego świadectwa Platon miał zainspirować powstanie oryginalnych teorii astronomicznych, stawiając przed uczonymi pracującymi w Akademii zadanie wytłumaczenia pozornie nieuporządkowanego ruchu planet na niebie. Hipotezy wysunięte wówczas przez Eudoksosa i Menechmosa, opracowane 
i skorygowane przez innych, stały się kamieniami milowymi starożytnej astronomii. Sam Platon przyjął w Timajosie jeszcze inną teorię, podobnie jak Speuzippos; Arystoteles zaadaptował zaś do swojej kosmologii teorię Eudoksosa.

Jakie wnioski można wyciągnąć na podstawie tego doniesienia? $\dot{Z}$ e nie istniała żadna ortodoksyjna teoria astronomiczna nauczana w Akademii przez Platona, a każdy z jej członków mógł zaproponować własną. Wspólny był natomiast problem, który Platon postawił jako naukowe wyzwanie dla wszystkich, w tym także dla siebie samego. Akademia jawi się zatem jako wspólnota pojedynczych, niezależnych badaczy, inspirowanych do samodzielnych badań przez „kierownika” czy „koordynatora” - kogoś, kto potrafi sformułować problem badawczy i nadzorować prace innych pod względem metodologicznym. Potwierdzają to pozostałe świadectwa, które wskazują na podobną rolę Platona w najważniejszych odkryciach matematycznych tego okresu: uczeni tej miary, co Eudoksos, Teajtet, Leodamas czy Filip z Opuntu, pracowali wspólnie w Akademii nad pewnymi zagadnieniami. Platon potrafil kierować ich uwagę na istotne, szczegółowe problemy, naprowadzać na twierdzenia i precyzować zasady metodologiczne. Jego największą zasługą w tej dziedzinie było rozbudzenie zainteresowania naukami matematycznymi wśród umysłów wykształconych filozoficznie. Ale pamiętajmy, że dla samego Platona matematyka była jedynie przygotowaniem do filozofii, ćwiczeniem poznania, które prowadzić miało wyżej, do czegoś ważniejszego niż przedmioty matematyczne (Arystoteles, Metafizyka 992a 30-b 1).

Mamy liczne dowody dysput i sporów, jakie członkowie Akademii prowadzili między sobą. Wszystko wskazuje na to, że Platońska nauka o Ideach nie była przedmiotem wykładów, lecz analiz i krytyki. Uczniowie dyskutowali jej aporie i proponowali własne rozwiązania. Znamy zarzuty, jakie wobec nauk swojego mistrza wysuwał Arystoteles, i wiemy jaką koncepcję zaproponował w jej miejsce. Ale od tego samego Arystotelesa (Metafizyka 1091a 29, b 22, b 32, 1085a 23) słyszymy o trudnościach, jakich w Platońskiej nauce doszukiwał się Speuzippos; a także o dyskusjach nad metodą diairezy (podziału) i sprzeczności, do jakich prowadzić ma przyjmowanie Idei jako autonomicznych bytów (Topiki 143b). Wiemy o odmiennych interpretacjach samych Idei w teoriach Speuzipposa, Eudoksosa, Ksenokratesa i Arystotelesa; o różnych sformułowaniach teorii pryncypiów; 
o odmiennych poglądach, jakie głosili Akademicy na temat związku między cnotą a przyjemnościami (Berti 2016: 17). Mówi nam to wiele o tym, jakiego rodzaju „nauczycielem” był Platon.

Wydaje się, że Platon nie prowadził żadnych wykładów, na których omawiałby z uczniami i tłumaczył im swoje pisma. W przekonujący sposób dowodził tego Cherniss, analizując spory między uczniami Platona (Cherniss 1945: 71). Mamy świadectwa dyskusji, jakie oni toczyli nad pewnymi szczegółowymi kwestiami, takimi jak Platońska koncepcja duszy czy natura Idei, ale także nad sposobem, w jaki należy odczytywać całe dialogi, na przykład Timajosa (Cherniss 1945: 74). Spory Akademików nad treścią tego ostatniego dialogu i różne jego interpretacje są szczególnie pouczające. Arystoteles (O powstawaniu i ginięciu 329a 8-24) dostrzega w Timajosie konkretne aporie i ogólniejsze sprzeczności, po czym stwierdza, że nie wie, jakie jest stanowisko Platona, ponieważ dialog jest w tej kwestii niejasny. $Z$ czego można wnioskować, że Stagiryta nie dysponował żadną autorską egzegezą Timajosa. Podejmuje natomiast polemikę $\mathrm{z}$ innymi interpretacjami, które - wszystko na to wskazuje - pochodzą od Ksenokratesa i Speuzipposa.

\section{Współpraca naukowa i relacie personalne w Akademii}

Wyłaniający się stąd obraz Akademii Platona kłóci się z naszymi wyobrażeniami o „szkole”, ukształtowanymi przez naszą tradycję uniwersytecką, ale również przez sposób, w jaki rozumiano szkołę filozoficzną w epoce hellenistycznej. Począwszy od III w. p.n.e. szkołę definiowała jej doktryna, określająca przede wszystkim sposób życia, do jakiego szkoła nakłaniała i przygotowywała. Doktryna była istotna, ponieważ służyła uzasadnieniu preferowanego modelu życia. Musiała się w związku z tym wyraźnie i łatwo odróżniać od doktryn konkurencyjnych szkół. W okresie najsilniejszej rywalizacji między szkołami filozoficznymi w Atenach ich nauki przybierały formę dogmatów (nowe znaczenie terminu dogmata), czyli głównych twierdzeń, a czasem streszczeń (Diogenes Laertios 1988: X, 139-154), które łatwo było sobie przyswoić i które precyzyjnie formułowały stanowisko szkoły. W tym względzie Akademia Platona stanowiła zupełne przeciwieństwo szkół hellenistycznych (Cherniss 1945: 82). 
$\mathrm{Z}$ całą jednak pewnością istniała w Akademii nauka, która była przedmiotem dyskusji i krytyki, skutkującej jej licznymi modyfikacjami. To ona, mimo wszelkich różnic między koncepcjami poszczególnych członków Akademii, definiowała ich jako „platoników”. Największym krytykiem Platońskiej nauki o Ideach wśród akademików był Eudoksos, ale nawet on przyjmował Idee jako niezbędny warunek istnienia (i poznania) rzeczy zmysłowych (Arystoteles, Metafizyka 991a 14, 1079b 18). Speuzippos, Ksenokrates i Arystoteles, najbardziej samodzielni uczniowie Platona, wypracowali własne koncepcje, które były próbami rozwiązania trudności, jakie dostrzegali w nauce swego mistrza (Reale 1999: 115 nn. i 123 nn.). Platon odniósł się do tej akademickiej krytyki i sporów wokół Idei w dialogu Parmenides, w którym pokazał, na jakie aporie z kolei napotykają te interpretacje jego nauki, które ignorują inteligibilny i niecielesny sposób istnienia Idei. Nie oczekiwał jednak, że jego uczniowie „nawrócą się" na jego koncepcję, tylko włączył się tym tekstem w polemikę z uczonymi, których uważał za przyjaciół i towarzyszy w poszukiwaniu prawdy. Nie uważał się też za kogoś, kto ostateczną prawdę posiadł, ponieważ wiedza o Ideach nie była, jego zdaniem, wiedzą w pełni demonstratywną (Państwo 532d; Parmenides $135 \mathrm{a}-\mathrm{b}$ ). Ideał wiedzy more geometrico miał swoje źródła właśnie w Akademii, gdzie już w czasach Platona powstawały pierwsze próby aksjomatyzacji geometrii, ale w przeciwieństwie do późniejszych arystotelików czy jednego z ostatnich scholarchów Akademii - Proklosa, Platon sądził, że filozofia, jako nauka uzasadniająca założenia wszystkich pozostałych nauk, musi dochodzić do swoich zasad inaczej. $Z$ wielu fragmentów pism Platona wynika, że chodzi tu o bezpośredni intelektualny wgląd, do którego prowadzi długa droga dialektycznych ćwiczeń. Należy przypuszczać, że takie właśnie ćwiczenia i dyskusje zalecał Platon i praktykował ze swoimi uczniami w Akademii (List VII, 340 c-d). A taka wiedza rodzi się w duszy, nie może pochodzić z zewnętrznego nauczania (Państwo 536e).

W kontekście naszych rozważań ważne są także doniesienia na temat relacji personalnych i standardów, jakie w tym względzie wprowadził w Akademii Platon. Słowem określającym towarzysza z Akademii było philos - przyjaciel. Arystoteles używa go zawsze, ilekroć mówi o Akademikach zbiorowo. Starożytna tradycja nazywała wręcz Akademię „szkołą przyjaciół” (Suda, hasło: „Akademia”). Niektórzy 
starsi uczniowie odchodzili z czasem z Akademii, by znaleźć sobie inną diatribe, jak to zrobili podobno Menedemos i Heraklides z Pontu. Ten ostatni po wyborze Ksenokratesa przystąpił na jakiś czas do Arystotelesowskiego Likejonu (Lynch 1972: 76, 79). Nie było to postrzegane jako jakieś odstępstwo ani negatywnie oceniane. Podczas dłuższej nieobecności Platona kierownictwo szkoły przejmował któryś z prosbyteroi i nie musiał to być ktoś wierny nauce mistrza, skoro funkcję tę pełnić mógł kiedyś Eudoksos (Vita Marciana 11, s. 99). Podobnie było z wyborem następcy - zarówno w przypadku Platona, jak i Arystotelesa, ich następcami zostali uczniowie najstarsi i najbliżsi im osobiście, nie zaś najwierniejsi głosiciele ich nauk. Akademia gościła wielu uczonych, niezależnie od ich poglądów, a o ile wiemy, również niezależnie od ich pochodzenia i statusu społecznego (Lynch 1972: 58, 79).

Z kolei określeniem najczęściej używanym w testiomoniach $\mathrm{w}$ odniesieniu do zajęć prowadzonych w Akademii i sposobu życia w niej jest synousia - to samo, które charakteryzowało relację erotyczno-wychowawczą w archaia paideia, a które Platon w odniesieniu do nauczania filozoficznego zdefiniował w swoich dialogach poprzez postawę Sokratesa. Inni towarzysze Sokratesa też zresztą utożsamiali jego nauczycielski talent ze „sztuką Erosa” i na odmiennych interpretacjach tego Sokratejskiego fenomenu budowali swoje własne koncepcje filozofii (Kahn 2018: rozdz. I; Morrison: 1994: 181-208). Arystoteles przeciwstawia czasem swoją metodę filozoficznej współpracy metodzie akademickiej i preferuje termin koinonia dla jej opisywania (Etyka nikomachejska 1164b 3, 1171b 29-1172a 9). Koinonia polega na współpracy uczonych bazujących na swojej wiedzy doświadczalnej i dzielących się nią z innymi, a więc na kumulowaniu wiedzy empirycznej (Arystoteles, Metafizyka 993a 30). Metodę dialektyczną zaś Stagiryta opisuje jako rozwlekłe rozważania prowadzone w oderwaniu od faktów ( $O$ powstawaniu $i$ ginięciu 316a 5-12). Dostrzega też w niej wpływ charakteru i emocji, które utrudniają osiągnięcie obiektywnego poznania (Etyka nikomachejska 1172a 20). Ale także u Arystotelesa przyjaźn jest istotnym czynnikiem wspierającym wspólne dochodzenie do prawdy. 


\section{Wnioski: Arystoteles jako uczeń Platona}

Przejdźmy wreszcie do głównej tezy artykułu i jego wniosków. Jaki paradygmat prezentuje relacja dwóch największych protagonistów greckiej filozofii? Zauważmy, że dla późnego antyku charakterystyczne było traktowanie filozofii Arystotelesa - głównie logiki i fizyki - jako wprowadzenia do „teologii” Platona. W neoplatonizmie nie był to przejaw eklektyzmu (jak to było w przypadku Antiocha z Askalonu, który zapoczątkował „ireniczną” tendencję Nowej Akademii), lecz autentycznego przekonania, że między naukami Platona i Arystotelesa nie ma istotowej sprzeczności, bowiem eksplorują oni inne obszary badawcze, ale ich tezy stanowią fundament spójnej philosophia aeterna. Zdawano sobie przy tym sprawę z różnic w rozstrzygnięciach konkretnych problemów, o czym zaświadcza Isagoga Porfiriusza, dzieło, które w średniowieczu postrzegano jako ukazujące konflikt autorytetów, ale które oryginalnie było podręcznikiem szkolnym, wprowadzającym (gr. isagoge znaczy „wprowadzenie”) w problematykę filozoficzną i ukazującym przykłady aporii, to znaczy takich problemów, które nie mają rozstrzygnięć ostatecznych i jednoznacznych, ale które da się „obejść” (gr. euporia) na różne sposoby - dlatego jeden filozof mógł je rozwiązywać tak, a drugi inaczej.

W czasach nowożytnych ukształtował się jednak wizerunek Arystotelesa jako odstępcy od platonizmu i surowego krytyka nauk mistrza. Jak zauważa Leszek Skowroński, na popularność tego stereotypu być może w największym stopniu wpłynęły nie analizy tekstów Stagiryty, lecz słynny watykański fresk Rafaela Szkota ateńska, na którym Platon i Arystoteles prowadzą niemy, ale symboliczny spór, wskazując przeciwne kierunki badań (Skowroński 2014: 15; Gerson 2005: 4). Trudno nie zauważyć, że Arystoteles poświęca w zachowanych tekstach wiele miejsca analizie i krytyce rozmaitych platońskich koncepcji. Jego próby rozwiązania najważniejszych problemów filozofii pierwszej, wymienionych w ks. B Metafizyki, formułowane są w opozycji do nauki o Ideach oraz teorii pryncypiów, a jego koncepcja prote philosophia, bazująca na wypracowanej przez Stagirytę nauce o kategoriach, stanowi odrzucenie pomysłu „protologii”, nauki o najwyższych zasadach wszelkiego bytu. Arystoteles, badając wieloznaczność pojęcia bytu, uznaje, że nauka o „bycie jako bycie” (później - trafnie bądź nie - nazwana „metafizyką”) nie dotyczy 
jednego przedmiotu („rodzaju”), lecz różnych sposobów jego orzekania, z których najważniejszą jest kategoria substancji. W wielu innych miejscach Stagiryta krytykuje zarówno tezy, jak i metodę platoników. W Etyce nikomachejskiej (I. 6) na przykład poddaje krytyce Platońską Ideę Dobra oraz koncepcję teoretycznej nauki o takim Dobru - jako nieprzydatną. Takie podejście może wywierać wrażenie, że Arystoteles w pewnym momencie swego naukowego życia zerwał z platonizmem i wypracował własną doktrynę (Jaeger 1948). Jednakże w świetle tego, co napisałem tutaj na temat relacji panujących między członkami Akademii oraz modelu współpracy naukowej, należy ocenić to wrażenie jako mylne. Arystoteles krytykuje nauki Platona i platoników, ale robi to jako platonik. To znaczy, że jego krytyka wychodzi z tych samych założeń, a jego kontrpropozycje mieszczą się w tym samym paradygmacie filozoficznym. Platonizm Stagiryty nie jest tym samym, co epikureizm epikurejczyków czy później tomizm tomistów. Arystoteles przekształcił doktrynę Platona, ale nie w większym stopniu, niż to zrobili Speuzippos czy Ksenokrates. Odrzucił Ideę Dobra jako najwyższego przedmiotu filozoficznego poznania, zwątpił w skuteczność samej dialektyki jako metody dochodzenia do prawdy, w wykładach przedkładał dosłowność i komunikatywność nad metafory, zaprzeczył autonomicznemu istnieniu Idei i skrytykował wiele innych elementów doktryny Platona. Ale jednocześnie uważał, że najważniejszym zadaniem filozofii jest wskazanie przyczyn wyjaśniających świat zjawisk w czterech aspektach (materialnym, formalnym, sprawczym i celowym), traktowaf filozofię za najdoskonalszy sposób życia, w którym realizuje się ludzkie powołanie - upodobnienie do boga. Dodajmy, że z zachowanych fragmentów wczesnych pism Arystotelesa można wnioskować, że tę własną interpretację platonizmu głosił Arystoteles już w Akademii, jako jej członek (Berti 2016: 22). Potwierdza to, zdaniem Bertiego, „klimat wielkiej wolności myślowej, jaki istniał w Akademii” oraz to, że „można było uważać się za platonika, jeśli nawet odrzucało się niektóre ważne doktryny sformułowane przez Platona"(Berti 2016: 24).

$\mathrm{Na}$ początku niniejszego artykułu nazwałem akademicki model relacji mistrz - uczeń „naukowym” i przeciwstawiłem go „szkolnemu”, mając w tym drugim wypadku na myśli hellenistyczne szkoły życia, których adepci, $\mathrm{z}$ własnego wolnego wyboru, stawali się wyznawcami szkolnej doktryny. Ten drugi model ma w istocie wiele wspólnego 
z religią, w której pojęcia „ortodoksja” i „herezja” mają jasne i wartościujące znaczenie. Ale faktem jest, że właśnie w antycznych szkołach filozoficznych, począwszy od III w. p.n.e., przynależność do szkoły bądź odejście do innej oceniane były w kategoriach ortodoksji i herezji, wierności i apostazji. Poświadcza to jedyny zachowany do naszych czasów antyczny podręcznik historii filozofii, Żywoty i poglady stynnych filozofów Diogenesa Laertiosa, który prezentuje dzieje myśli filozoficznej jako historię różnych doksai, głoszonych przez konkurujące ze sobą szkoły. Nowożytne podręczniki do dziś powielają ten schemat.

Akademia Platona, jak próbowałem wykazać, nie była jednak tego rodzaju „szkołą”. Przenikał ją duch wolnych badań, nieskrępowanych doktryną mistrza. Arystoteles od początku swojej naukowej działalności w Akademii prezentował intelektualną niezależność, prowadząc tam nawet własne wykłady $z$ retoryki (Lynch 1972: 84). Jego filozoficzna metoda, jak już wspominałem, różniła się pod wieloma względami od Platońskiej. W przeciwieństwie do mistrza, Stagiryta ufał w edukacyjną wartość pisma, sporządzał notatki (pragmateiai) do wykładów, które systematycznie uzupełniał i poprawiał (Düring 1950: 58). Przedkładał też regularne wykłady nad dyskusję, a w działalności pedagogicznej wykorzystywał wykresy, rysunki, mapy, a także dbał o to, by słuchacze byli wcześniej wprowadzeni w temat i metodę wykładu (Jackson 1920: 191-200). To wszystko sprawiło, że działalność naukowa i wychowawcza Likejonu miała inny charakter niż działalność prowadzona w Akademii (Lynch 1972: 84 nn.). Ale pomimo tych wszystkich różnic, Arystotelesa należy uznać za prawdziwego platonika - nie tylko najwybitniejszego, ale także najwierniejszego naukom swego mistrza. Nie miało to nic wspólnego z doktrynalną ortodoksją. Stagiryta pozostał wierny najbardziej istotnemu przesłaniu Platonizmu - że filozoficzny model życia, polegający na dążeniu do wiedzy, która uczynić może człowieka "podobnym do boga" (homoios theo; Platon, Teajtet 176b; Arystoteles, Etyka nikomachejska 1177b 26-1178a 8), jest jego prawdziwym powołaniem, wyzwaniem, któremu mimo ograniczeń ludzkiej natury jest w stanie podołać. Arystotelesowski ideał bios theoretikos, wbrew stereotypowym interpretacjom, przeciwstawiającym go Platońskiemu (Skowroński 2014: 103 n.), jest prawdziwym dowodem jego platonizmu. 


\section{Bibliografia}

Arystofanes (1963). Chmury, przeł. A. Sandauer, Warszawa: Czytelnik.

Arystoteles (1990). Dzieła wszystkie, t. 1, przeł. K. Leśniak, Warszawa: Wydawnictwo Naukowe PWN.

Arystoteles (1990). Dzieta wszystkie, t. 2, przeł. K. Leśniak, Warszawa: Wydawnictwo Naukowe PWN.

Arystoteles (1996). Dzieta wszystkie, t. 5, przeł. D. Gromska, L. Regner, W. Wróblewski, Warszawa: Wydawnictwo Naukowe PWN.

Berti E. (2016). Profil Arystotelesa, przeł. M.A. Wesoły, Poznań: Wydawnictwo Naukowe Wydziału Nauk Społecznych UAM.

Bloch H. (1940). Historical Literature of the Fourth Century B.C., „Harvard Studies in Classical Philology", suppl. 1, s. 303-376.

Cherniss H. (1945). The Riddle of the Early Academy, Berkeley (CA): University of California Press.

Diogenes Laertios (1988). Żywoty i poglady stynnych filozofów, przeł. I. Krońska, K. Leśniak, W. Olszewski, Warszawa: Wydawnictwo Naukowe PWN.

Düring I. (1950). Notes on the History of the Transmission of Aristotle's Writings, „Göteborgs Högskolas Årsskrift”, t. 56, s. 37-70.

Gerson L.P. (2005). Aristotle and Other Platonists, Ithaca (NY): Cornell University Press.

Jackson H. (1920). Aristotle's Lecture-Room and Classes, "Journal of Philology", t. 35, s. 191-200.

Jaeger W. (1948). Aristotle: Fundamentals of the History of His Development, Oxford: Oxford University Press.

Kahn Ch.H. (2018). Platon i dialog sokratyczny, przeł. M. Filipczuk, Warszawa: Fundacja Świętego Mikołaja; Redakcja „Teologii Politycznej”.

Lynch J.P. (1972). Aristotle's School: A Study of Greek Educational Institution, Berkeley (CA): University of California Press.

Morrison D.R. (1994). Xenophon's Socrates as Teacher, [w:] The Socratic Movement, red. P. Vander Waerdt, Ithaca (NY)-London: Cornell University Press, s. 181-208.

Nock A.D. (1933). Conversion, Oxford: Oxford University Press.

Paczkowski P. (2009). Czego nie wiemy o Akademii Platona, [w:] Philosophiae Itinera. Studia i rozprawy ofiarowane Janinie Gajdzie-Krynickiej, red. J. Jaskóła, A. Olejarczyk, A. Pacewicz, Wrocław: Wrocławskie Wydawnictwo Oświatowe, s. 355-363.

Platon (1987). Listy, przeł. M. Maykowska, Warszawa: Wydawnictwo Naukowe PWN.

Platon (1990). Państwo, przeł. W. Witwicki, Warszawa: Wydawnictwo Akme.

Platon (1999). Dialogi, t. 1-2, przeł. W. Witwicki, Kęty: Wydawnictwo Antyk. 
Reale G. (1996). Historia filozofii starożytnej, t. 2: Platon i Arystoteles, przeł. E.I. Zieliński, Lublin: Wydawnictwo Naukowe KUL.

Reale G. (1999). Historia filozofii starożytnej, t. 3: Systemy epoki hellenistycznej, przeł. E.I. Zieliński, Lublin: Wydawnictwo Naukowe KUL.

Saffrey H.D. (1968). Ageōmetrētos mèdeis eisitō. Une inscription légendaire, „Revue des études grecques”, t. 81, s. 67-87.

Skowroński L. (2014). Arystoteles o celu ludzkiego życia. Ku nowej interpretacji „Etyki nikomachejskiej”, Nowa Wieś nad Drwęcą: Wydawnictwo Rolewski.

Vinogradoff P. (1922). Outlines of Historical Jurisprudence, t. 2, Oxford: Oxford University Press, s. 119-127.

\section{ADRES DO KORESPONDENCJI}

Dr hab. Przemysław Zbigniew Paczkowski, prof. UR

Uniwersytet Rzeszowski

Instytut Filozofii

e-mail: pacz.przem@wp.pl 